DOI 10.22363/2313-2329-2021-29-1-56-63

UDC 338

Research article / Научная статья

\title{
China's innovation race: future leader or outsider?
}

\author{
Marina S. Reshetnikova \\ Peoples' Friendship University of Russia (RUDN University), \\ 6 Miklukho-Maklaya St, Moscow, 117198, Russian Federation \\ $\square$ reshetnikova-ms@rudn.ru
}

\begin{abstract}
Today two main innovative determinants influence China's position in the race to global leadership in artificial intelligence. The aim of the research was to assess Chinese innovative potential according to two criteria: artificial intelligence talents and hardware base. The analysis has provided a conclusive answer to the question about the prospects of China to achieve the position of a scientific and technological superpower. The presented data shows that global competition in artificial intelligence has toughened and there is a certain lag in the competence of Chinese talents and in the development of breakthrough microelectronic technologies. However, the dynamics of the Chinese artificial intelligence sector growth and the Big Government legal actions indicate that the changes may come very soon. Due to the growing uncertainty and technological confrontation between main innovative and technology competitors, the victory in the global race for China's artificial intelligence sector may not take place.
\end{abstract}

Keywords: China, AI, competitive innovation, R\&D

Acknowledgements: This research was funded by the Faculty of Economics of the RUDN University, grant No. 060326-0-000.

Article history: received 13 October 2020; revised 14 November 2020; accepted 14 December 2020.

For citation: Reshetnikova, M.S. (2021). China's innovation race: Future leader or outsider? RUDN Journal of Economics, 29(1), 56-63. http://dx.doi.org/10.22363/2313-2329-2021-29-1-56-63

\section{Китай и инновационная гонка: будущий лидер или аутсайдер?}

\author{
М.С. Решетникова \\ Российский университет дружбы народов, \\ Российская Федераџия, 117198, Москва, ул. Миклухо-Маклая, д. 6 \\ $\square$ reshetnikova-ms@rudn.ru
}

\begin{abstract}
Аннотация. Рассматриваются основные инновационные детерминанты, влияющие на лидерство Китая в области искусственного интеллекта, а также дается оценка, по каким из этих показателей удалось добиться успеха. Проведен сравнительный анализ по двум критериям, влияющим на инновационный потенциал: квалификация и общее количество пула специалистов, занятых в сфере искусственного интеллекта, и уро-
\end{abstract}

(C) Reshetnikova M.S., 2021

(c) () This work is licensed under a Creative Commons Attribution 4.0 International License https://creativecommons.org/licenses/by/4.0/ 
вень развития материально-технической базы. Полученные результаты позволили сделать неутешительный вывод о перспективах Китая по достижению позиции научного и технологического лидера. Мировая конкуренция в области искусственного интеллекта ужесточилась, и налицо определенное отставание китайского сектора искусственного интеллекта от существующих лидеров, в первую очередь США, в области развития прорывных микроэлектронных технологий. Тем не менее динамика роста китайского сектора искусственного интеллекта и действия правительства указывают на то, что положительные изменения могут произойти очень скоро.

Ключевые слова: Китай, искусственный интеллект, инновационная гонка, НИОКР

Благодарности: Исследование выполнено при финансовой поддержке экономического факультета Российского университета дружбы народов, проект № 060326-0-000.

История статьи: поступила в редакцию 13 октября 2020 г.; проверена 14 ноября 2020 г.; принята к публикации 14 декабря 2020 г.

Для цитирования: Reshetnikova M.S. China's innovation race: future leader or outsider? // Вестник Российского университета дружбы народов. Серия: Экономика. 2021. T. 29. № 1. C. 56-63. http://dx.doi.org/10.22363/2313-2329-2021-29-1-56-63

\section{Introduction}

On July 8, 2017, at the meeting of the State Council of the People's Republic of China, a national strategy for the development of technology was approved, which includes the "Program for the Development of Artificial Intelligence of a New Generation" (State Council, 2017). For the first time at the state level, it consolidates the country's development strategy as a "scientific and technological superpower", the decisive condition for the implementation of which is China's world leadership in the development of artificial intelligence.

The PRC government expects a lot from the development of technologies in the field of artificial intelligence. First of all, the recovery of entire sectors of the economy after the COVID-19 pandemic (Chen et al., 2020).

The consistent implementation by the Chinese government of the strategy for the development of artificial intelligence has determined its rapid entry into the world race for leadership. Today, the Chinese sector of artificial intelligence has come close to the United States, the main player, and has overtaken it in some positions (O’Meara, 2019). China's decisive trump cards in this battle are unprecedented government funding and a huge amount of data generated by Chinese users (Reshetnikova, 2020). The problems that hinder his leadership remain unchanged. The first is the number and level of scientific and practical competencies of the pool of specialists. The second is lagging behind in breakthrough microelectronic technologies. There is an understanding in China that without overcoming the problems in these innovative determinants, leadership cannot be achieved. The result was the transformation of China's state strategy for the development of artificial intelligence.

The aim of this work was to analyse this transformation and assess the implications of its implementation for the development of the artificial intelligence sector in China.

\section{Literature review}

The main focus of modern innovation is the development of AI. The undisputed leader in citation is the book of the former president of Google China Kai Fu-Lee "AI Superpowers: China, Silicon Valley, and the New World Order" de- 
dicated to the development of the AI sector in China (Demchak, 2018). In this book the author presents an analysis of the current state of the Chinese AI. The main outcome from this study is that China has already outstripped the United States in AI development.

The response to the work of Kai Fu-Lee was an equally significant study of the English innovator Jeffrey Ding "Deciphering China's AI dream" (Ding, 2018). It details the milestones in China's AI sector. The analysis of the state strategy, methods and actions of the Chinese government, which ensured the rapid development AI, is carried out. J. Ding mainly analyses the problems and miscalculations in the Chinese innovation strategy.

Both presented works, due to the significant amount of statistical material, are of great interest for studying the Chinese experience in developing state innovation strategies. However, according to the author, both studies suffer from a certain subjectivity. In addition, their conclusions and statements by 2020 are not entirely relevant. The development of the world economy is so uncertain and rapid that significant changes in the global paradigm are already happening. That is why it is important to analyse the transformation of China's strategy aimed at overcoming the problems that hinder the development of national AI.

\section{Research results and discussion}

\section{Artificial intelligence - China's new area of international competition}

Based on the international practices of innovation leaders, Beijing decides to transform its innovation strategy towards the development of AI technologies, as the main driver of the national economy. It is expected that this will enable China to significantly improve its position in the global market by increasing its position in the division of labour.

Adoption of the "Program for the Development of Artificial Intelligence of a New Generation" in 2017 is the main milestone document in China's struggle for leadership in AI. It defines the strategic goals, the timing of their achievement, presents the bureaucratic mechanism of work and funding.

It is clear that the government's decision to include China in the race for leadership in a new area of international competition has found inspired support in Chinese business. By the beginning of the first half of 2020, the explosive growth of the Chinese AI sector reached the level of \$ 29.5 million, which corresponds to a 10 -fold increase in the industry in just 3 years. And this is against the background of the problems in the global economy caused by the pandemic (iiMedia Research Group, 2018). The reason for such a large-scale success in the development of Chinese AI lies, according to the author, in the unique state support. In addition to the previously mentioned program, the Ministry of Industry and Informatization has issued a "Three-Year Action Plan to Promote the Development of the Next Generation Artificial Intelligence Industry." The document of the Ministry of Science and Technology of the PRC echoes it, in which a list of 13 technological projects that ensure the development of the technological base of the AI sector is highlighted at the legislative level (Ministry of Industry and Information Technology, 2017).

Since 2018, research and development in the field of AI has been among the six national priorities for the development of the Chinese economy. This pro- 
vides government funding on an unprecedented scale. The author concludes that such a combination of these two strategic factors in the innovation sector in China is observed for the first time since the national innovation system reforms in the 2000s.

\section{Al development factors in China}

The NIS reform implemented by the Chinese government in the 2000s was certainly very effective and successful (Zhou, Liu, 2016). However, its implementation took almost 10 years. Today there is simply no such time reserve. Modern innovative strategies must be succinct and specific, which allows a quick achievement of the desired result. And this, according to the author, is taken into account by innovative consultants in the Chinese government. That is why the innovative strategy for the development of the Chinese AI sector very specifically sets the circumstances of the movement towards world leadership in this area.

China obviously understands that in order to win the modern innovation race, it is necessary to provide sustainable leadership in the following innovation factors:

- fundamental research that forms the theoretical basis;

- applied developments (number of patents);

- the number and quality of AI talents;

- the modern AI ecosystem and related industries.

The concretization of the innovative strategy for the AI development has brought its results. By the end of 2019, this sector of the Chinese innovation system is leading both in the number of conducted research and in the registration of intellectual property rights (SCMP Research, 2020).

The development of the AI business ecosystem and related industries is also favourable. The government has identified technology giants that dominate the AI market and are affiliated with government agencies. Today there are four major donor companies. These are Baidu (self-driving vehicles), Alibaba (smart cities), Tencent (computer vision for medical diagnostics) - the so-called BAT group in China, and a fairly young company iFlyTek (voice assistance) (Tencent AI Lab, 2019). Companies are provided with unprecedented financial support from state program funds. These funds can only be spent on $\mathrm{M} \& \mathrm{~A}$ and further development of AI startups. The Ministry of Industry and Technology alone allocated practically \$ 978 million for these purposes in 2019 (SCMP Research, 2020). Thanks to such a large-scale financial support, donor companies, massively absorbing startups, have the opportunity to practically immediately implement their developments in various products and services in the field of artificial intelligence, regardless of the prospects of success (Altenburg et al., 2008)

However, today this is the only example in the Chinese AI of successful combination in quantitative and qualitative research indicators. In other areas, according to the author, China is playing a cruel joke with excessive adventurism, lack of training of specialists (development and creation of algorithms), unresolved problems with applied developments, primarily in microelectronics (lack of national chips), and hobby for scaling. However, these problems are quite traditional for the development of the NIS of the PRC (Reshetnikova, 2018). And if adventurism is an invariable national trait, then the last two can be eliminated. 


\section{Resolving Al talents problems}

The Chinese government's innovative strategy to accelerate the AI development has yielded results (Wang, 2017). By the beginning of 2020, the pool of Chinese specialists in terms of the number of people employed in AI came close to the pool of the closest competitor of the United States and amounts to 2.8 million people (Roberts et al., 2020).

Their scientific and practical competences have also significantly increased. China's breakthrough leap in registration of intellectual property rights for AI developments is a clear evidence for it. In 2019 alone, the country filed 30 thousand patent applications on artificial intelligence, which is 2.5 times more than the same indicator in the United States (Table).

Table

Al patents obtained in China by inventive activity

\begin{tabular}{lccc}
\hline \multicolumn{1}{c}{ Patents obtained by inventive activity } & $\mathbf{2 0 1 5}$ & $\mathbf{2 0 1 7}$ & $\mathbf{2 0 1 9}$ \\
\hline Total patents & 10890 & 12740 & 30000 \\
Invention patents & 220 & 294 & 600 \\
Utility Model Patents & 6050 & 6985 & 16500 \\
Design patents & 4620 & 5461 & 12900 \\
\hline
\end{tabular}

Source: author's calculations based on the Al ecosystem in China, 2020. Retrieved September 7 , 2020, from https://daxueconsulting.com/ai-in-china-white-paper/

However, the scientific value of the Chinese wave of AI research is not great; among the patents filed, $87 \%$ are for utility models and industrial designs, and only $2 \%$ for basic research (Table).

According to the calculations of the Ministry of Industry and Informatization of the PRC, about 5 million specialists are needed to successfully solve the tasks set for the AI sector (Reshetnikova, 2020). To achieve this goal, since 2018, the Ministry of Science and Education has launched university training programs in AI at 35 universities. More than 40 universities have introduced training in programs related to the AI sector, such as robotics and big data technologies.

The practice of attracting foreign specialists to improve the scientific competence of the national innovation sector started in 2008, with the launch of the program of the State Council of the People's Republic of China "Thousand Talents". Based on it, high-class foreign scientists can move to the country without bureaucratic formalities (Wu et al., 2020). They receive research space and funding in the form of government grants, which can amount to 1 million yuan.

According to the author, this reversal of the "open door" strategy is caused by the desire of China, using the achievements of world science, to accelerate the development of national research. Modern research, primarily in the field of AI, requires a very expensive analytical and research network makerspace and a high scientific level of the staff. It is not possible to quickly solve this problem. Despite all the financial and political efforts of the government and private business in China, by 2018 only eight makerspaces are functioning, equipped with the Fablab research complex, which is part of the global research analytical network and whose results are accepted by the world scientific community (Perrault et al., 2019).

As expected by the Chinese government, the implementation of the presented transformation strategy for solving the personnel issue was supposed to help the Chinese AI sector overcome the lag in the level of AI talents. 


\section{Chinese microchip is the fastest in the world}

For the technological success of the Chinese AI sector, it is equally important to overcome the lag in fundamental technologies, primarily in microelectronics, namely in the development of the semiconductor base.

By the beginning of 2019, the Chinese industry produced only $16 \%$ of the consumed chips and microcircuits, and only half of them were produced by national companies located in the country. The dependence of the Chinese AI sector on imports of foreign components, mainly American ones, is extremely high.

It is obvious that the Chinese government hoped to continue to use the achievements of innovative leaders. However, the tightening of competition in the AI technology market, which began with the arrival of President Trump in the White House, introduced significant complications to the Chinese import of high-tech components.

The situation with China's leading AI companies ZTE and Huawei showed Beijing how dangerous dependence on foreign technology is in the modern world.

To implement it, the State Investment Fund was created under the Ministry of Industry and Informatization of the PRC to support Chinese manufacturers of chips and microcircuits. By the end of 2019, it had already accumulated over $\$ 31.5$ billion. The costs of implementing the subprogram for the development of the AI element base by 2025 should approach $\$ 140$ billion (Figure).

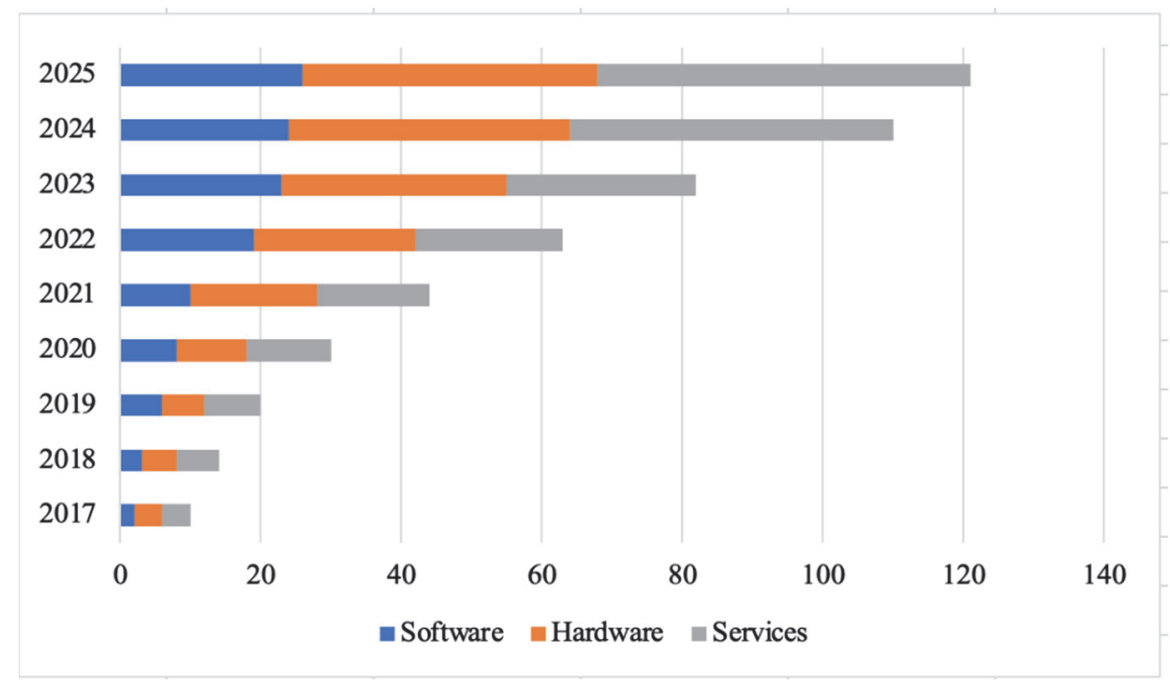

Figure. Government spending on the production of microcircuits for the Al sector in China, by areas, \$ million

Source: author's construction based on China Al Report 2020. Retrieved October 13, 2020, from https://www.scmp.com/china-ai-report

Government support for chip developers and manufacturers does not only cover direct funding. Tax incentives and administrative preferences provided to them are also important. This has already yielded results. By the beginning of 2020, almost a third of the world's technological startups in the field of AI with a capitalization of more than $\$ 1$ billion are operating in China. This list is headed by the already mentioned three BAT.

Borrowing tactics remain another element of China's state strategy for developing a technological base. Namely, encouraging national companies to merge and take over foreign market participants. 
With government support, Baidu has established three research centers in Silicon Valley in the United States. Tencent has set up an AI research center in Seattle. The author is interested in the fact that the government of China is financially present in all these centers, being the owner of 5 to $9 \%$ of their capital. Research by the Rhodium Group has shown that the growth of Chinese venture capital investments in the US technology sector in five years exceeded more than $100 \%$ from $\$ 316$ million in 2013 to $\$ 3.1$ billion in 2018 (Rhodium Group, 2020).

This is the current strategy of Beijing in the direction of overcoming the lag in breakthrough fundamental technologies, primarily in microelectronics, namely in the development of the semiconductor base. It is expected that its successful implementation will allow the national AI sector to become a world leader.

\section{Conclusions, proposals, recommendations}

Today it is clearer than ever that the end of the Cold War ended not only the confrontation between the two social systems of capitalism and socialism. There has been a change in the entire world economy, due to the development of a catch-up development trend in it. A number of peripheral states have successfully implemented this strategy. It allowed them to quickly achieve economic growth through the industrialization of national industries. The countries, innovative leaders, who moved environmentally harmful and not modern production from their national territories were also not at the loser. At the same time, their dominance in the high-tech sector remained.

China is the main winner in the implementation of the catch-up development strategy. In a historically short period of time, from a backward country in which life expectancy did not exceed 40 years, it developed into the second largest economy in the world, while remaining in the shadow of innovative leaders.

Now this shadow weighs on China. It no longer wants to be a global factory. Today, the development strategy of its economy - the state of "scientific and technological superpower" will provide the leadership in the AI development. Consistently implementing, since 2017, the state strategy for the development of a new generation of artificial intelligence, Beijing confidently took the second place in the level of AI development, behind only the United States (Trump, 2019).

Competition in the innovation market is getting tougher. This explains the actions of the two world giants: increased protectionism in the domestic market in China and the growth of prohibitive measures against Chinese companies in the United States. The world is again on the verge of a cold war. Only now the confrontation lies not in the plane of politics, but in the success of the development of high technologies.

\section{References}

Altenburg, T., Schmitz, H., \& Stamm, A. (2008). Breakthrough? China's and India's transition from production to innovation. World Development, 36(2008), 325-344. DOI: 10.1016/j.worlddev.2007.06.011.

Cho, A. (2016). 'Huge leap forward': Computer that mimics human brain beats professional at game of Go. Science. doi:10.1126/science.aae0281.

Demchak, C. (2018). "Four horsemen of AI conflict: Scale, speed, foreknowledge, and strategic coherence." In N.D. Wright (Ed.), AI, China, Russia, and the global order: Technological, political, global, and creative perspectives (chapter 13, pp. 100-106). Washington DC, Department of Defense. Retrieved September 1, 2020, from https://nsiteam.com/ social/wp-content/uploads/2018/12/AI-China-Russia-Global-WP_FINAL.pdf 
Ding, J. (2018, March). Deciphering China's AI dream. Future of Human University, University of Oxford. Retrieved September 1, 2020, from https://www.fhi.ox.ac.uk/wp-content/ uploads/Deciphering_Chinas_AI-Dream.pdf

iiMedia Research Group. (2018). Special report on China's artificial intelligence industry. Retrieved September 1, 2020, from http://www.sppm.tsinghua.edu.cn/eWebEditor/UploadFile/ China_AI_development_report_2018.pdf

Ministry of Industry and Information Technology. Science and Technology Department. (2017, December 12). Three-year action plan for promoting development of a new generation artificial intelligence industry (2018-2020). Retrieved September 1, 2020, from https://www.miit.gov.cn/n1146290/n4388791/c5960863/content.html

O'Meara, S. (2019). China's ambitious quest to lead the world in AI by 2030. Nature, 572, 427-428. https://doi.org/10.1038/d41586-019-02360-7

Perrault, R., Shoham, Y., Brynjolfsson, E., Clark, J., Etchemendy, J., Grosz, B., Lyons, T., Manyika, J., Mishra, S., \& Niebles, J.C. (2019, December). The AI index 2019 annual report. AI Index Steering Committee, Human-Centered AI Institute, Stanford University, Stanford, CA.

Reshetnikova, M. (2018). Innovation and entrepreneurship in China. European Research Studies Journal, 21(3), 506-515.

Reshetnikova, M.S. (2020). China's AI experience: Industrial digitalization. RUDN Journal of Economics, 28(3), 536-546. http://dx.doi.org/10.22363/2313-2329-2020-28-3-536-546

Rhodium Group. (2020). The US - China investment hub. Retrieved September 1, 2020, from https://www.us-china-investment.org/fdi-data

Roberts, H., Cowls, J., Morley, J., et al. (2020). The Chinese approach to artificial intelligence: An analysis of policy, ethics, and regulation. AI \& Soc. https://doi.org/10.1007/s00146-020-00992-2

SCMP Research. (2020). China AI report 2020. Retrieved September 1, 2020, from https://www.scmp.com/china-ai-report

State Council. (2010). Decision of the State Council on accelerating the cultivation and development of strategic emerging industries (No. 32). Beijing.

State Council. (2017, July 8). New generation of artificial intelligence development plan. State Council Document No. 35. Retrieved September 1, 2020, from http://www.gov.cn/ zhengce/content/2017-07/20/content_5211996.htm

Tencent AI Lab. (2019, July 8). Technological ethics at intelligent era - reshape trustworthiness in digital society. Beijing, Tencent Research Institute. Retrieved December 1, 2020, from https://tisi.org/10890 (In Chinese.)

Trump, D.J. (2019, February 11). Executive order on maintaining American leadership in artificial intelligence. Washington, DC, The White House. Retrieved September 1, 2020, from https://www.whitehouse.gov/presidential-actions/executive-order-maintaining-americanleadership-artificial-intelligence/

Wang, Z. (2017). The economic rise of China: Rule-taker, rule-maker, or rule-breaker? Asian Survey, 57(4), 595-617. https://doi.org/10.1525/as.2017.57.4.595

Wu, W., Huang, T., \& Gong, K. (2020). Ethical principles and governance technology development of AI in China. Engineering, 6(3), 302-309. https://doi.org/10.1016/j.eng.2019.12.015

Zhou, Y., \& Liu, X. (2016). Evolution of Chinese state policies on innovation. In Y. Zhou, W. Lazonick \& Y. Sun (Eds.), China as an Innov. Nation (pp. 33-67). Oxford University Press, Oxford. DOI: 10.1093/acprof:oso/9780198753568.003.0002.

Chen, B., Marvin, S., \& While, A. (2020). Containing COVID-19 in China: AI and the robotic restructuring of future cities. Dialogues in Human Geography, 10(2), 238-241. DOI: $10.1177 / 2043820620934267$.

\section{Сведения об авторе / Bio note}

Решетникова Марина Сергеевна, кандидат экономических наук, доцент кафедры экономикоматематического моделирования экономического факультета Российского университета дружбы народов. E-mail: reshetnikova-ms@rudn.ru.
Marina S. Reshetnikova, $\mathrm{PhD}$, Associate Professor of Economic and Mathematic Modelling Department at Economic Faculty of the Peoples' Friendship University of Russia (RUDN University). E-mail: reshetnikova-ms@rudn.ru. 